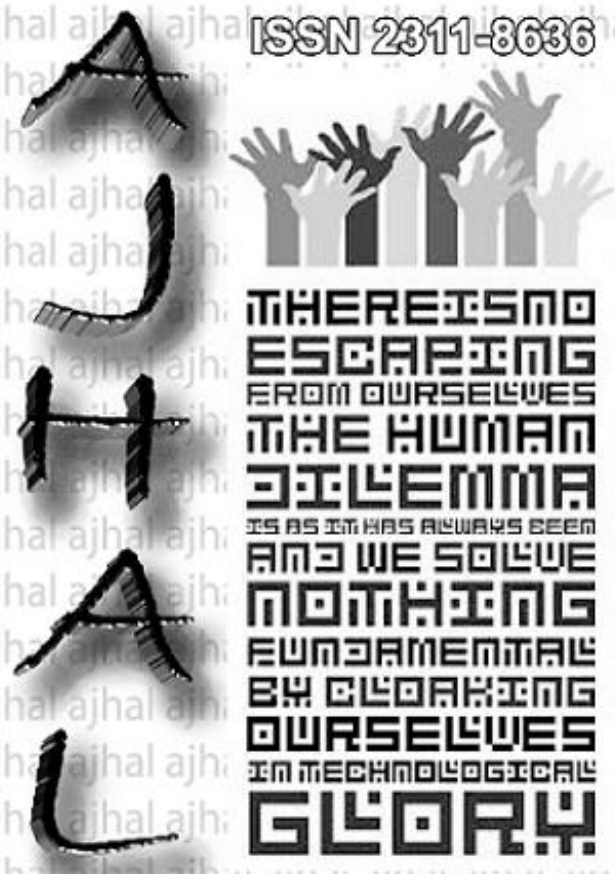

Vol 2, No. 2/2015

Asjan Jourmal of Humanity, Art and Litergatulue 


\title{
A Theological Study of Nissim Ezekiel's Religious Outlook
}

\section{Goutam Karmakar}

Assistant Teacher, Department of English, Bhagilata High School (H.S), Uttar Dinajpur, West Bengal, INDIA

ISSN: 2311-8636 (Print)

ISSN: 2312-2021 (Online)

Volume 2, Number 2/2015

DOI prefix: 10.18034/ajhal

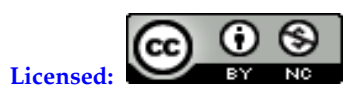

Source of Support: Nil

Conflict of Interest: None Declared

Email for correspondence: goutamkrmkr@gmail.com

some of his verses.

\section{ABSTRACT}

As the centuries passed by, the galaxy of Indian English Poetry become increasingly crowded. But the scenario was not like this during the early years. It is because only a few stars shine there, and Nissim Ezekiel is the pole star. His poetry contains so many aspects, themes, motives and symbols that sharpen and shape his poetic world. His poetry often shows irony, emotion, love, manwoman relationship, self- consciousness, a sense of discipline and self - criticism. He shows his concern for both modern and urban art and culture with the touch of Indian ethos and local colour. But as an Indian poet, he shows his thinking about God and religion in a vivid way. He also shows his changing view towards God and Indian theology in his poems. In this paper, I have tried to show Ezekiel's religious outlook and aspects through

\section{Key Words: Myth, God, Lord, Prayer, Theology}

\section{Presentation}

Nissim Ezekiel is one of the greatest poets of Indian English Literature. He in his poems tries to show India's cultural heritage, identity, deep-rooted ideals. As an Indian, he has a deep sense of religion, man-God relationship, spiritual values and theologies. He shows how all these play an effective role in different kinds of socio-religious scenario. His reading of Indian religious books, mythologies left a great impact on his mind, and he wants to penetrate this impact into his poetry.

Before the start of this discussion about his theology, I want to show what God means to him. He uses the word 'God' so many times in his poetry. Sometimes like a modern poet, he takes God as a normal human being. But at the same time, he praises, advices and rebukes God. He wants to learn the Ultimate truth, and for this reason, he urges God to give him adversities and misfortunes in order to know the truth. As he says:

\author{
"Kick me around \\ a bit more, O Lord \\ I see at last \\ There is no other way \\ For me to learn
}

Your simpliest truths." ((JSAL, 133) 
But as a modernist poet, he sometimes shows that one can easily communicate with God in the day by day speech. And in these lines he shows how an urban man tries to contact with God in a simple, friendly way. As he says:

"Be drunk, occasionally

but not with gin

or whisky

may the Lord

use you up for ends

beyond your means

so you know what drunkenness

really means." (Collected Poems, 280)

But he also shows that God is someone with whom we can share our depression, frustration and anger also. In these lines, he shows his attempt to correct even God:

"Lord, few there are that trouble me

fewer still that rise up against me

Be thou a shield for them as for me." (Collected Poems, 253)

Even in 'Collected Poems', he is ready to rebuke him and even shows his anger and disgust. As these lines show:

"How can I breathe freely

if you breakfast the teeth of the ungodly?" (Collected Poems, 253)

Ezekiel even shows his disgust and lack of faith in God and his disciples. In his 'Guru', he shows that these Gurus are fake, diplomatic and don't know the actual meaning of prayer, religion, spiritual learning and salvation. In his 'Guru', he says about them:

"But when we learn

the saint is still a faithless friend,

obstinate in argument

ungrateful for favourite done,

hard with servants and the poor,

discourteous to disciples, especially men." (Guru)

In his 'Egotist Prayers', he shows how prayer changes its form now-a-days. Here he denies doing work without result that Lord Krishna says in Bhagwat Gita. Here he rejects all sorts of advice that God has given to man. Even he forgets his duty and duty towards God. As these lines clearly show the decline of religious faith from rural to an urban level and also show the naked truth of Indian society:

"Do not choose me, O Lord, to carry out thy purposes.

I am quite worthy, of course,

But I have my own purpose.

You have plenty of volunteers

to choose from, Lord

why pick on me, the selfish one?" (Egotist Prayers)

But it is not always same as he also believes in Supreme Being's power. He also shows man's relationship with God and man's place in the universe. What a man can know about God is what God reveals to him and also to know God completely is hard, an unfathomable reality. As he shows in his $16^{\text {th }}$ Hymns in Darkness:

"You are master

neither of death nor of life

Belief will not save you, 
nor unbelief.

All you have

Is the sense of reality

Unfathomable

As it yields its secrets

Slowly One by One." (16 $6^{\text {th }}$ Hymns in Darkness)

Ezekiel also wants to show that we have to remove veils that cover our outer image and existence in order to know God. He shows this in 'Theological':

"I've stripped off a hundred veils

and still there are more

that cover you creation

Why are you so elusive?

Even as myself, my very own

Incontrovertible, unexceptional

Self, I feel I am disguised." (Theological)

Often we find Ezekiel in a prayer mode in his poetry. He realizes that it is not possible for mankind to acquire virtue which they don't have and he knows that human being will always commit vices. And he believes that it is God who somehow responsible for it as he creates mankind. So it is God's duty to save man. As he says these in the second of the 'Poster Prayers':

“The vices I've always had

I still have

The virtues I've nearer had

I still do not have

From this human way of life

Who can rescue man

If not his maker?

Do thy duty, Lord!" [JSAL, 133]

At the same time he turns to God to seek knowledge and wisdom. He prays to God to give him virtue, knowledge and power to understand him. As he clearly shows these in these lines:

"Give me as much knowledge

as I need, and then some more.

The extra since or two

from your bread of love and truth

is only for me greed.

You know what lies beyond my hunger.

Overlook, O Lord, my love of food." (Poster Prayers)

Ezekiel knows that wealth, property and material pleasure are desirable things, and he wants to be rich by knowing the fact that a rich man can't go to heaven. He also knows that if a camel can go there through the eye of a needle, then he can also go there. So, he prays:

"Let me be, O Lord,

The Camel of the Higher Income Group

Who passes smooth through

The eye of that needle." (JSAL,134)

Apart from his religious outlook, he has also shown his theological aspect in his poems. Since his childhood, Ezekiel reads Bhagwat Gita and Upanishad. And his religious poems show these books' influence on him. Also, he shows society's changing attitude towards 
religion and God. In his 'Tribute to Upanishads', he shows how this book helps him to gain knowledge of real self. As he says:

"To feel that one is

to drive oneself

in a kind of hearse-

the destination is obvious." (Tribute to Upanishads)

Indian mythology appeals him very much. Lord Krishna's preaching regarding the mystery of life and self left deep impression on him. He wants to search the mystery of life leaving the worldly life and the next life. He shows us what Lord Krishna shows to Arjun:

"The secret locked within the seed

becomes my need and so

I shrink to nothingness

Within the seed." (Collected Poems, 205)

Vedic Hymns, Bhagwat Gita have left a mark on him. As a result, he realizes that one can understand God after complete devotion and surrender before the Supreme Being. He also shows that it is God who can show how to come out of all chaos. Again he reminds us of Lord Krishna's advice to Arjun. Here he takes the form of a common man, a city dweller to come closer to his readers. In these lines, we find all these:

"He has lost faith in himself

And found faith at last

All forms of God

and God in all forms." (Collected Poems, 219-220)

Ezekiel's spiritual quest, humanistic voice, his disillusionment caused by fake, false and unsubstantial world is found in 'Theological'. Here he shows two aspects of life. On one hand, he tries to rebuild man's relationship with society, Nature and God. And on the other hand, he tries to show that the realization of the ultimate truth of God is ultimate savior of mankind. And to achieve this, a broad framework is needed. As he shows these two aspects in these lines:

\section{"Lord, I am tired of being wrong}

Your truth

is too momentous for man

And not always useful." (Collected Poems.156)

Ezekiel also shows his anxiety for the modern man who does not believe God. But it is the God who can do everything. Indian myth and theology are well shown in his poem 'Counsel'. Here he wants to show man's knowledge of what he needs and what he does not need:

"Success at the moment

is not in your interest." (Counsel)

Hindu Mythology can also be seen in his 'Morning Prayer'. In this period, he believes firmly in God and tell him to make him a good human being. He thus says here using the reference of 'Panchtava' theory of Hindu Mythology:

"...certainly

in kinship with the sky

Air, Earth, Fire, Sea-

and the fresh inward eye." (Morning Prayer) 
Not only Hindu mythology, but Christian mythology is also seen in his poetry, Using the reference of Adam and Eve, he tells us to remove all false knowledge as knowledge is that thing which is tasted by First Man and Woman. Also he advices that the mankind should now fast as they have acquired so much knowledge whether good or bad. As he says:

"...Learn to fast

Do without, be absent

Keep the eyes closed." (Collected Poems, 229)

In poems like 'The Cur', 'Enterprise', we find the same theme as God is everywhere, and we don't need to go to any particular place in search of God. It can be found in the home. As he says:

"Home is where we have to earn grace." (Collected Poems.25)

Ezekiel as a religious Indian poet wants to show even his natives' socio-religious attitude. He shows the confusion and dilemma of a middle aged man as they have to divide they time into spiritual and material world. They can't choose only one world because both materialistic pleasure and spiritual bliss are needed in life. In 'At Fifty', he shows these:

"I do not want the ashes

of the old fire but the flame itself.

Interest in the secret of renewed

is sign of age.

no longer secret." (At Fifty)

Ezekiel firmly believes in the power of God. And he wants to warn all kinds of people about, not too proud and boast of them. God is the only controller and master of all. So, we have to be normal before the Supreme Being. As he says:

"You are master

neither of death nor life

Belief will not save you

nor unbelief." (Collected Poems, 222)

As a modernist poet, he is deeply influenced by English modernists' poets. He reads Eliot's 'The Waste Land' and echoes the same theme of selfless giving, Daan and Dutta. As he says:

"Express your gratitude

By giving what you have to give

You may get nothing in return

And bear your restlessness with grace." (Collected Poems, 229)

\section{CONCLUSION}

So in the concluding lines, it can be said that his religious outlook is vast and deep rooted. He sees God in various ways with Indian ethos, mythology and sensibilities. But it is his God for whom he surrenders himself completely and wants his natives' complete surrender before God. Actually Ezekiel's religious outlook is also totally Indian in form and content. And I agree totally with what P.P.Mehta said about him: "As a poet, he is aware of his cultural milieu and native problems. His sharp sensibility enables him to grapple with the situation around him; without nostalgically recalling his stay in England or drawing of a foreign land. He gives careful thought to his ideas, medium of expression and form of words and phrases; and does not attempt to depict what is gaudy and inane and more adolescent. In him, the reflective and philosophical strains are predominant." 


\section{REFERENCES}

Dwivedi, A. N, Studies in Contemporary Indo-English Verse. Bareilly: Prakash Book Depot, 1984

Ezekiel, Nissim. Collected Poems 1952-1988, Delhi: Oxford University Press,Ed. II, 2005

Kher, Inder Nath. Journal of South Asian Literature,11. Numbers 3-4, 1976 (Abbreviated as JSAL)

King Bruce, Modern Indian Poetry in English, New Delhi: Oxford University Press, 1987

Naik, M.k., Dimentions of Indian English Literature, New Delhi: Sterling Publishers, 1984

Pandey, Birendra (Ed). Indian Poetry in English. New Delhi: Atlantic Publishers \& Distributors, 2001

Patil, Mallikarjun. Indian English Literature: A Post-Colonial Response. New Delhi: Sarup \& Sons Publishers, 2005

Raghu, A. The Poetry of Nissim Ezekiel. New Delhi: Atlantic Publishers \& Distributors, 2002

Ramamurti, K.S, Twenty-five Indian Poets in English. New Delhi, Macmillan India Limited, 1995

Rao, R. Raj. Nissim Ezekiel: The Authorized Biography. New Delhi: Penguin Books India (P) Ltd, 2000

This article is is licensed under a Creative Commons AttributionNonCommercial 4.0 International License. Attribution-NonCommercial (CC BYNC) license lets others remix, tweak, and build upon work non-commercially, and although the new works must also acknowledge \& be non-commercial.

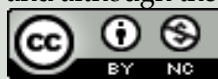

How to Cite: Karmakar G. 2015. A Theological Study of Nissim Ezekiel's Religious Outlook Asian Journal of Humanity, Art and Literature, 2, 71-76. 


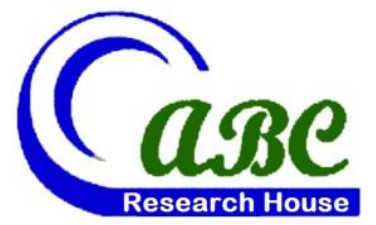

- Off Pantai Dalam, Kuala Lampur, Malaysia

- Road \# 4, Shyamoli, Dhaka-1207, Bangladesh

- 3900 Woodhue Place, Alexandria, VA 22309, USA

http://journals.abc.us.org/ / www.abcjournals.net

Asian Business Consortium (ABC) is a multi-disciplinary research, training, publishing, digital library supporting and service house. Though founded in 2010 as the Business and Computing organization of Asia, it was reconstituted as the ABC in 2011. It has been working for creating and nurturing talents in USA, Malaysia and Bangladesh since its inception. The objectives of consortium are solely centered round the welfare and humane attitude of the founders who enthusiastically took up this noble cause and materialized it with a view to promote research and educational activities for the encouragement of scholars to develop their knowledge, to publish their analysis oriented scientific researches in international Journals, books, the task of organizing workshops, seminars, conferences, training, personality development programs and allied services.

In addition to research activities, $A B C$ provides a good number of scholarships to the poor and meritorious students at various levels of education throughout the world. It plays an important role in the field of research by funding research projects and publishing the research papers. This consortium will unquestionably become the mouth-piece of the dark horses and unacknowledged scholar whose endowed and commendable contributions shall be provided an outlet keeping in mind the greater good of the larger society of the world.

$A B C$ runs the following international referred journals for creating a platform to share the thoughts of professionals, scholars and academicians throughout the world.

\section{ABC Publications (ABC Journals)}

- Asian Accounting and Auditing Advancement (4A Journal)

- Asian Business Review (ABR)

- Asian Journal of Applied Sciences and Engineering (AJASE)

- Global Disclosure of Economics and Business (GDEB)

- $\quad$ ABC Journal of Advanced Research (ABC-JAR)

- International Journal of Reciprocal Symmetry and Theoretical Physics (IJRSTP)

- American Journal of Trade and Policy (AJTP)

- Asian Journal of Humanity, Art and Literature (AJHAL)

- Malaysian Journal of Medical and Biological Research (MJMBR)

- Asia Pacific Journal of Energy and Environment (APJEE)

- $\quad$ Engineering International (EI)

- $\quad$ ABC Research Alert (Online)

Each journal home page provides specific information for potential authors and subscribers. Open access policy, the quick review process, rich editorial boards and quality publications have already made $A B C$ Journals unique. ABC Journals are published under the direct supervisions of renowned academicians of the world.

Collaboration in Conference: $\mathrm{ABC}$ considers high-quality conference papers for publication. Please contact us for detailed information.

Collaboration in Publishing: If you like to start writing a book, propose a new journal or advertise in $\mathrm{ABC}$ journals, please feel free to contact us. 